\section{Mond Nickel Fellowships}

The Mond Nickel Fellowships for 1957 have been awarded to Mr. E.J. Williams (John Summers and Sons, Ltd.) and Mr. R. J. D. Acheson (Mufulira Copper Mines, Ltd.). The Committee now invites applications for Fellowships of an approximate value of $£ 900$ $\mathfrak{f 1 , 2 0 0}$ for 1958. Fellowships will be awarded to selected candidates of British nationality with degree or equivalent qualifications to enable them to obtain wider experience and additional training in industrial establishments, at home or abroad. Further information can be obtained from the Secretary, Mond Nickel Fellowships Committee, 4 Grosvenor Gardens, London, S.W.1. Completed application forms are required by June I.

\section{Progress in Atomic Power}

THE United Kingdom Atomic Energy Authority is to hold a Conference at Harwell on June 11, at which recent developments in nuclear reactor technology will be discussed with representatives of British industry. Accommodation will be available for about two hundred representatives from industry. Requests for further details and for reservations should be made to the Director (Industrial Liaison Office), Building 329, Atomic Energy Research Establishment, Harwell, Nr. Didcot, Berkshire, not later than March 15.

\section{Gordon Research Conferences}

ThE Gordon Research Conferences for 1958 will be held during June 9-August 29 at Colby Junior College, Now London, Now Hampshire; New Hampton School, New Hampton, New Hampshire; and Kimball Union Academy, Meriden, New Hampshire. The Conferences, established to stimulate research in universities, research foundations and industrial laboratories, consist of informal meetings, scheduled lectures and free discussion groups intended as a means of disseminating information and ideas which otherwise would not be reslized through the normal channels of publication and scientific meetings. No publications are prepered as emanating from the Conferences, attendance at which is limited to one hundred persons. The programme includes ceramics, chemistry, structure and physiology of bones and teeth, magnetic resonance, nuclear chemistry, radiation chemistry, toxicology and safety evaluation, and corrosion. Requests for additional information, or applications to attend, should be addressed to $W$. George Parks, Director, Department of Chemistry, University of Rhode Island, Kingston, Rhode Island.

\section{Aeronautical Research}

THE Combustion and Propulsion Panel of the Advisory Group for Aeroneutical Research and Development, North Atlantic Treaty Organization, will hold its third colloquium in Palermo, Sicily, during March 17-21. The meeting will be largely devoted to consideration of current propulsion problems. Five themes will be developed during the meeting, with one day devoted to each. They are : power plant requirements related to aircraft mission ; interaction of the combustion systems with other engine components ; noise ; combustion; aerophysical chemistry.

The Group's Wind Tunnel and Model Testing Panel will also sponsor a meeting, in Freiburg im Breisgau, Germany, during April 22-25. The subjects which will be discussed during the four-day meeting will include the historical development of ballistics, high-velocity guns, range techniques and long-range missiles.

\section{Lady Tata Memorial Trust Scholarships and Fellow- ships}

The Trustees of the Lady Tata Memorial Fund invite applications for grants, scholarships or fellowships for research on diseases of the blood, with special reference to leukæmia, in the academic year beginning on October 1 . In view of the affinity between leukæmia and other forms of neoplastic disease, candidates with programmes of research on any aspect of malignent disease which may throw incidental light on problems of leukæmia will be eligible for consideration. Grants of variable amount are made for research expenses or to provide scientific or technical assistants for senior workers. Scholarships are awarded for the personal remuneration of workers carrying out approved research under suitable direction; their normal value will be $£ 600$ per annum. In addition, the Trustees may award one or more Lady Tata Memorial Research Fellowships to workers with considerable research experience, with stipends of $£ 1,200$ per annum. Further particulars and forms of application may be obtained by writing to the Secretary of the (European) Scientific Advisory Committee, Lady Tata Memorial Trust, Chester Beatty Research Institute, Fulham Road, London, S.W.3. Applications must be submitted before March 31, and the awards will be announced by the Trustees in June. The grants, scholarships and fellowships offered by the Trust are open to suitably qualified investigators of any nationality, working in any country in which it will be possible to make pryments in the coming academic year.

\section{Oversea Service Division, Colonial Office}

THE following appointments have recently been made in the Oversea Service Division, Colonial Office : H. B. Ambrose (agricultural officer, Kenya), research officer, Nyasaland; A. de K. Frampton (agricultural adviser to the controller, Development and Welfare Organizations, Barbados), deputy director of agrieulture, Barbados; V. E. Gale (principal agricultural officer, Western Nigeria), assistant director of agriculture, Western Nigeria; L. Green (field officer (agriculture), Uganda), senior field officer (agriculture), Uganda; V. R. James (assistant superintendent of public gardens, Jamaica), superintendent of public gardens, Jamaica; G. S. Scott (provincial tsetse officer, Tanganyika), agricultural officer, Uganda; W. S. Steel (entomologist, Game and Tsetse Control Department, Northern Rhodesia), chief entomologist, Game and Tsetse Control Department, Northern Rhodesia; W. E. Lewis (assistant conservator of forests, Nyasaland), conservator of forests (Division of Afforestation), Nyasaland; J. L. Masson (assistant conservator of forests, Northern Nigeria), senior assistant conservator of forests, Northern Nigeria ; C. A. M. Nash (assistant conservator of forests, Northern Nigeria), senior assistant conservator of forests, Northern Nigeria; I. Paul (assistant conservator of forests, Sierra Leone), senior assistant conservator of forests, Sierra Leone; J. D. Todd (assistant conservator of forests, Mauritius), assistant conservator of forests, Northern Rhodesia; L. H. Myers (assistant director of surveys, Jamaica), supernumerary deputy director of surveys, Jamaica ; P. D. L. Guilbride (veterinary 